\title{
CRISIS MANAGEMENT AS A PART OF THE STRATEGIC MANAGEMENT SERVICE COMPANIES
}

\section{Pero Petrović}

Institut za međunarodnu politiku i privredu, Beograd, Srbija

\author{
Aleksandar Živković \\ Ekonomski fakultet, Beograd, Srbija
}

CMESTE

JEL Category: F15, K33, K40

\begin{abstract}
Apstakt
Uslovi privređivanja uslužnih preduzeća, u manje-više svim zemljama sveta, karakteriše kompleksnost i fluktuacija. Posebni uslovi privređivanja, naročito u uslovima intezivnih procesa globalizacije i svetske finansijske krize, pokazuju stalno smanjenje zarađivačkih sposobnosti uslužnih preduzeća a time $i$ pogoršavanje finansijskog položaja. U pitanju je svojevrsna kriza poslovanja preduzeća u nedovoljno adaptibilnom privredno-sistemskom ambijentu. Krizni menadžment dolazi do izražaja pojavom krize preduzeća koja se, primarno, vezuje za situaciju razvoja u kojoj je preduzeće dostiglo kritičnu tačku sa određenim obeležjima. Međutim, teško je jednom definicijom sva obeležja krize preduzeća. Ipak, u nešto užem smislu, krizu preduzeća treba shvatiti kao proces u kojem se, neplanirano i nepoželjno, ugrožavaju postavljeni osnovni ekonomski ciljevi preduzeća - cilj očuvanja uloženog kapitala, cilj dobitka (rentabiliteta), cilj očuvanja likvidnosti i solventnosti preduzeća. Stoga se prepoznaju četiri osnovne faze krize poslovanja preduzeća: strategijska kriza, kriza rentabiliteta, kriza likvidnosti, nelikvidnost $i$ zaduživanje. Prepoznavanje i identifikovanje simptoma krize, te otkrivanje relevantnih uzroka kriza preduzeća uopšte, a naročito u uslovima svetske finansijske i ekonomske krize posebno, pretpostavke su za uvođenje posebne forme upravljanja preduzećem u krizi, odnosno kriznog menadžmenta.
\end{abstract}

Ključne reči: krizni menadžment, strategijski menadžment, hotelska preduzeća;

\section{Abstract}

Economic conditions, service companies, in more or less all the countries of the world, characterized by complexity and fluctuation. Special economic

Address of the corresponding author:

Pero Petrović

拝=" pera@diplomacy.bg.ac.rs conditions, particularly in conditions of rapid globalization process and the global financial crisis, have shown a constant decrease profit ability of 
service companies and thus worsening financial position. It is a kind of crisis of operations of insufficiently adaptable business-system environment. Crisis management comes to the fore a crisis, enterprises, primarily related to the development of the situation in which the company has reached a critical point with certain characteristics. However, it is a definition of all the hallmarks of the crisis the company. However, in a narrower sense, the crisis companies should be seen as a process in which, unplanned and unwanted, endanger the fundamental economic objectives of the company - the goal of preserving the capital invested, the goal of profit (profitability), the purpose of liquidity and solvency of the company. Therefore, identify four main phases of the crisis of business enterprises: strategic crisis, the crisis of profitability, liquidity crisis, insolvency and debt. Recognizing and identifying the symptoms of the crisis, and to discover the causes of the crisis of relevant companies in general, and particularly in the context of the global financial and economic crisis, in particular, conditions for the introduction of specific forms of business management in a crisis, and crisis management.

Keywords: crisis management, strategic management, hotel companies;

\section{UVOD}

Suština kriznog menadžmenta još uvek nije pravilno shvaćena i dovoljno široko prihvaćena u privrednom životu, a posebno u uslužnoj industriji. Adekvatne upravljačke aktivnosti menadžmenta uslužnih preduzeća u "normalnim" uslovima i okolnostima poslovanja preduzeća pretpostavka su za uspešnu realizaciju misije i ciljeva preduzeća, odnosno izbegavanja krize. Ipak, krize preduzeća su ponekad i neminovnost, a ponekad rezultat više različitih i simultanih uzročnika. Razumljivo, preduzećem treba upravljati $\mathrm{i} u$ kriznim situacijama, ali tada menadžment preduzeća poprima nešto dugačija obeležja krizni menadžment. Krizni menadžment treba shvatiti kao posebnu formu upravljanja hotelskim preduzećem od najvišeg prioriteta. Rad u poslovnom okruženju uslovljava kompanije da posluju pod značajnim pritiskom promena, koje često dovode do kriznih situacija. Najveći broj kriza, bez obzira da li su endogenog ili egzogenog porekla, predstavlja posledicu nedovoljnog i neadekvatnog prilagođavanja promenama kompanija, koje ne posvećuju dovoljno pažnje događajima u okolini i okruženju. Sve krizne situacije zahtevaju formulisanje i razvoj strategije koja će omogućiti što kvalitetnije rešavanje problema koje sa sobom nose krizne situacije. Različitost kriznih situacija nameće i izbor same strategije, koja treba da odbrani hotelska

\footnotetext{
${ }^{1}$ Ovako učinjeno pojmovno određenje krize preduzeća svakako treba razlikovati od pojmova koji se često koriste u praksi, kao što su konflikti, poremećaji, agonije, katastrofe i slično, a koji se ne mogu smatrati sinonimima.
}

kompaniju u javnosti. Prvi korak podrazumeva definisanje problema korišćenjem pouzdanih informacija. Neophodno je i postavljanje merljivih ciljeva komunikacije, kako bi se krizom moglo ovladati na najbolji način.. Neosporno, problemi koji se ne rešavaju prerastaju u krizu ali i u kriznim situacijama neophodno je da krizni menadžment obezbedi nastavak uobičajenih radnih aktivnosti da li kompanija treba da prekine novu, tek započetu, marketinšku kampanju? Da li treba trenutno prestati sa osvežavanjem Internet portala kompanije? Adekvatan odgovor na ovakva i slična pitanja se moraju naći u odgovoru koji neće dalje razvijati i povećavati krizu.

\section{KRIZA I POSTUPANJE PREDUZEĆA U KRIZI}

Kriza preduzeća predstavlja "kritičnu tačku ili trenutak" u nizu neuspešnih upravljačko-poslovnih aktivnosti, koje su dovele do stanja u kome je preduzeće egzistencijalno ugroženo ${ }^{1}$. Otkrivanje i sprečavanje, posebno savlađivanje krize su u domenu aktivnosti menadžmenta preduzeća. U takvim okolnostima, menadžment preduzeća poprima obeležja kriznog menadžmenta kao specifične forme upravljanja preduzećem. Kriza poslovanja preduzeća, simptomi i uzroci (posebno načini savladavanja krize kroz postupak privatizacije) imaju svoje specifičnosti, što kriznom menadžmentu daje dodatnu ulogu i značaj². Veliki

2 lako suštinsko razumevanje kriza uopšte pobuđuju pažnju teoretičara iz više naučnih oblasti (istorije, medicine, politike, psihologije, društvenih nauka) naslovom zadati pristup usmerava pažnju posebno na oblast ekonomije. 
broj kompanija je kritikovan zbog spore reakcije tokom krizne situacije samo zato što su trudili da prikupe što više informacija vezanih za problem. Ukoliko je za prikupljanje informacija neophodno nekoliko sati, menadžer za odnose $s$ javnošću, mora da se obrati javnosti $\mathrm{i}$ da je obavesti da kompanija radi na uklanjanju krize. Ćutanje u ovakvoj situaciji je kontraproduktivno, jer javnost mora da shvati da se radi na uklanjanju problema i niko neće upućivati kritike organizaciji koja je svesna problema. Ukoliko je neko i kritikuje, takav pristup se uglavnom ocenjuje kao jednostran ili neprijateljski. Takvu javnost koja se trudi da kompromituje aktere kriznih situacija je nemoguće izbeći i kompanije treba da uče iz toga, jer je to onda koristan podatak - organizacija može onda uvek da nasluti i predvidi reakcije javnosti koje se negativno ističu. Klasifikacija kriza preduzeća može biti izvršena prema različitim kriterijumima, kao što su, na primer prema: lokaciji i broju uzroka krize, trajanju procesa, vrsti delovanja, i drugim kriterijumima (Senić, 1996, pp. 32-41). Međutim, s aspekta ugroženosti realizacije prethodno postavljenih konkretnih osnovnih ekonomskih ciljeva preduzeća, posebno imajući u vidu redosled otkrivanja, prihvatljiva je sledeća klasifikacija kriza preduzeća:

a. kriza likvidnosti preduzeća predstavlja poslovno-finansijsku situaciju predeuzeća u kojoj ono nije u mogućnosti da svoje dospele novčane obaveze izmiruje u utvrđenim rokovima njihovog dospeća, ili da in uopšte izmiruje ${ }^{3}$.

b. kriza uspeha preduzeća se pojavljuje u uslovima kada preduzeće ne može da realizuje cilj očuvanja uloženog kapitala i cilj dobitka, odnosno predstavlja poslovnofinansijsku situaciju preduzeća u kojoj je zarađivačka sposobnost preduzeća dovedena u pitanje. Međutim, dok se kriza likvidnosti odnosi na neželjeni nepovoljan likvidetni položaj, dotle se kriza uspeha odnosi na nepovoljan rentabilitetni položaj preduzeća; dakle na pojavu gubitka ili nedovoljnog dobitka u poslovanju. Prepoznavanje krize uspeha je otežanije u odnosu na krizu likvidnosti, naročito u nestabilnim, inflatornim uslovima privređivanja.

Tabela br.1 Hijerarhizacija, kriza preduzeća i informaciona podrška nosiocima kriznog menadžmenta

\begin{tabular}{|c|c|c|c|c|}
\hline $\begin{array}{l}\text { Nosioci kriznog } \\
\text { menadžmenta }\end{array}$ & $\begin{array}{l}\text { Vrsta krize } \\
\text { preduzeća }\end{array}$ & $\begin{array}{l}\text { Segmenti } \\
\text { računovodstva i krizni } \\
\text { menadžment }\end{array}$ & $\begin{array}{l}\text { Računovodstveni } \\
\text { izveštaji i krizni } \\
\text { menadžment }\end{array}$ & $\begin{array}{c}\text { Računovodstveni } \\
\text { izveštaji kao upravljački } \\
\text { instrumenti }\end{array}$ \\
\hline Top menadžment & 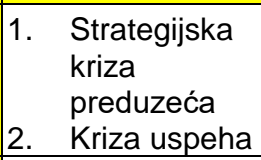 & \begin{tabular}{|l} 
1. \\
Finansijsko \\
2. \\
\end{tabular} & 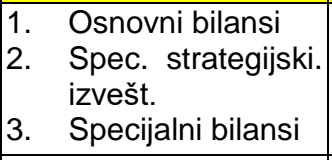 & $\begin{array}{l}\text { - Kontrolni } \\
\text { - Dispozitivni } \\
\text { - Kontrolno-dispozit. }\end{array}$ \\
\hline $\begin{array}{l}\text { Operativni } \\
\text { menadžment }\end{array}$ & $\begin{array}{l}\text { Kriza uspeha } \\
\text { preduzeća }\end{array}$ & 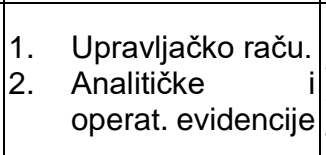 & $\begin{array}{|ll|}\text { 1. } & \text { Bilans uspeha } \\
\text { 2. } & \text { Interni bilans usp. } \\
\text { 3. } & \text { Kalkulacija cene k } \\
\text { 4. } & \text { specijalni izveštaji } \\
\end{array}$ & $\begin{array}{l}\text { - Kontrolni } \\
\text { - Dispozitivni } \\
\text { - Kontrolno-dispozit }\end{array}$ \\
\hline $\begin{array}{l}\text { Finansijski } \\
\text { menadžment }\end{array}$ & $\begin{array}{ll}\text { 1. } & \text { Kriza } \\
\text { likvidnosti } \\
\text { 2. } & \text { Kriza } \\
& \text { solventnosti }\end{array}$ & 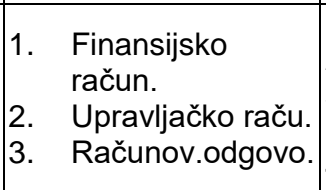 & $\begin{array}{ll}\text { 1. } & \text { Osnovni bilansi } \\
\text { 2. } & \text { Interni bilansi } \\
\text { 3. } & \text { Izveštaji o } \\
\text { 4. } & \text { performa. } \\
\text { 4. } & \text { Specijalni bilansi }\end{array}$ & $\begin{array}{l}\text { - Kontrolno-dispozit. } \\
\text { - Kontrolno-dispozit. } \\
\text { - Kontrolno-dispozit. } \\
\text { - Kontrolno-dispozit. }\end{array}$ \\
\hline
\end{tabular}

Izvor: (Weston, Mitchell, \& Mulherin, 2004)

c. strategijska kriza preduzeća predstavlja poslovno-finansijsku situaciju preduzeća u kojoj je, zbog propuštenih ili neadekvatno odabranih i realizovanih strategija za ostvarivanje misije i ciljeva preduzeća, trajnije ugrožena osnova za ostvarivanje uspeha cilja očuvanja uloženog kapitala i cilja rentabiliteta. $\mathrm{Na}$ primer, to mogu biti propuštene ili neadekvatne strategije u vezi s jačanjem tehnološke prednosti, reduciranjem
3 Kriza likvidnosti se prva ispoljava kao neplanirano nepoželjno stanje, a rezultat je neadekvatnog planiranja i neefikasne kontrole novčanih tokova, odnosno izostanka sinhronizovanog priliva i odliva gotovine.
Razlozi pojave krize likvidnosti se, uglavnom, mogu pripisati neadekvatnoj finansijskoj strukturi i pojavi gubitaka u poslovanju. 
troškova, osvajanjem novih tržišta i slično. Sažeto, šematsko predstavljanje odnosa između vrsta krize preduzeća i izvora računovodstvene informacione podrške kriznom menadžmentu preduzeća, može se predstaviti na sledeći način.

Računovodstveni informacioni sistem dobija dodatnu, posebnu ulogu i značaj u periodu krize preduzeća. Posebnost se ogleda u tome što računovodstveni izveštaji sa odgovarajućim relevantnim informacionim sadržajima poprimaju ulogu kontrolnih $\mathrm{i} / \mathrm{ili}$ dispozitivnih instrumenata $u$ upravljanju krizom preduzeća, posebno krizom uspeha i finansijskom krizom.

Krizni menadžment, shvaćen kao proces upravljačkih aktivnosti odvija se kroz pet glavnih faza: planiranje, organizovanje, vođenje, kontrola i odlučivanje. Osnovni cilj kriznog menadžmenta je savlađivanje krize odnosno nastojanje da se preduzeće učini dugoročno sposobnim za opstanak na konkurentskoj tržišnoj sceni. Krizni menadžment, shvaćen kao institucija, podrazumeva nosioce kriznog menadžmenta odgovarajuće eksperte koji, angažovani kao zastupnici kapitala, upravljanju preduzećem u krizi radi njegovog saniranja. Prilikom prikupljanja informacija o nastaloj situaciji, u kompaniji se formira posebni, centralni sektor gde te informacije pristižu i gde se obrađuju. Takav centar se obično naziva krizni štab. Krizni štab predstavlja neku vrstu logistike i daje podršku celokupnoj komunikaciji tokom krizne situacije. U slučaju nesreća, koje prouzrokuju velike krize, neophodno je organizovanje posebne lokacije za medije sa svim neophodnim tehničkim uslovima za press-centar, sa koje će im se predstavnici kriznog štaba obratiti. Krizni menadžment, pre svega, koristi računovodstveni informacioni sistem (RIS) preduzeća zbog svojih karakteristika predstavlja veoma pouzdan i relevantan podsistem u sklopu poslovnog informacionog sistema preduzeća. Realizacijom računovodstvene procedure u poslovnim knjigama stvara se baza računovodstvenih podataka, koja služi kao osnova za sastavljanje brojnih i različitih računovodstvenih izveštaja

\footnotetext{
4 Računovodstveni izveštaji mogu poticati iz različitih segmenata RIS-a, - Finansijskog računovodstva,
}

namenjenih eksternim i internim informacionim korisnicima.

Naravno, za zadati aspekt razmatranja, od posebne važnosti su računovodstveni izveštaji namenjeni kriznom menadžmentu preduzeća ${ }^{4}$. Ovi izveštaji namenjeni kriznom menadžmentu preduzeća za potrebeposlovno finansijskog odlučivanja mogu biti različiti po formi, sadržini, nameni i rokovima dostavljanja. Osnovni računovodstveni izveštaji iz Finansijskog računovodstva - bilansi preduzeća, za potrebe kriznog menadžmenta, uglavnom se dodatno pripremaju i, kao predmet analize, posebno interpretiraju top menadžmentu odnosno upravnom odboru preduzeća.

Osim zvaničnih računovodstvenih izveštaja pribavljenih iz finansijskog računovodstva (bilans stanja, uspeha, tokova gotovine, konsolidovanog $i$ poreskog bilansa) koji se posebno pripremaju i interpretiraju, sve poslovne službe ili sektori preduzeća pripremaju izveštaje namenjenih kriznom menadžmentu preduzeća. To mogu biti: specijalni bilansi, specijalni strateški izveštaji, interni bilansi stanja i uspeha, i posebno kalkulacije cene koštanja učinaka. Računovodstveni izveštaji (iz računovodstva odgovornosti) se uglavnom odnose na izveštaje o performansama po užim organizacionim celinama - segmentima preduzeća i posebno na specijalne izveštaje. Svi izveštaji po sektorima i službama, s aspekta upravljačkih aktivnosti menadžmenta mogu imati kontrolnu i dispozitivnu ulogu.

Stručni izveštaji koji obuhvataju informacione sadržaje na bazi nastalih tokova vrednosti $u$ preduzeću, uglavnom imaju ulogu kontrolnog instrumenta u oceni ostvarenja ciljeva preduzeća ili planskih zadataka uopšte. Oni izveštaji stručnih službi koji sadrže projektovane, planske tokove vrednosti preduzeća i/ili njegovih segmenata poprimaju ulogu dispozitivnog (usmeravajućeg) instrumenta u upravljačkim aktivnostima menadžmenta.Svaka promena ima različite manifestacije. Samo praćenje promena u okruženju nije dovoljno jer kompanija ne može sve da spreči i upravo se zbog toga mora pripremati za moguće konfliktne i krizne situacije. Planiranje

Upravljačkog računovodstva i Računovodstva odgovornosti. 
komunikacijskih aktivnosti pre same krize nosi sa sobom sledeće aktivnosti (Novak, 2001, p. 134):

- predviđanje i prepoznavanje potencijalnih kriznih situacija;

- oblikovanje tima koji će koordinirati krizom;

- prepoznavanje ciljnih javnosti u kriznom položaju;

- oblikovanje komunikacijskih strategija taktika;

- određivanje i oblikovanje efikasnih puteva komunikacije za ciljane javnosti pogođene krizom i smanjenje štete po ugled kompanije;

- testiranje i adaptacija komunikacijskog plana;

- određivanje i osposobljavanje menadžera odnosa s javnošću;

- priprema i formiranje kriznog centra zaduženog za komunikaciju;

- priprema check-liste za eventualnu krizu i glavnih informacija o kompaniji.

Mnoge kompanije izbegavaju simulacije realnih situacija, jer vesti mogu biti loše, a opasnost da se javi panika realna. I na to je veliki broj kompanija preosetljiv smatrajući da su svesni i da znaju šta bi se moglo dogoditi, ali im nije od velike važnosti da to i ozvaniče. Ipak je neophodno proći kroz pripreme ma koliko one bile naporne i bolne kako bi se među zaposlenima stekla sigurnost. Postoji niz problema koji mogu da se pojave, a sa kojima kompanija mora ozbiljno da računa (Antoni, 2005, pp. 111-112):

- Masovna panika, koja može obesmisliti i najbolje planove;

- Previše aktera koji iz najrazličitijih razloga žele da budu glasnogovornici;

- Ljutnja i nezadovoljstvo zbog velike nasrtljivosti medija;

- Zlonamerne pretpostavke i spekulacije o razlozima za zadovoljenje medija ili ličnih motiva;

- Potcenjivanje istinskog nivoa javnog interesa;

- Nespremnost da se zatraži pomoć;

- Oglušavanje o savete aktera „prijatelja kompanije" koji žele da pomognu;

- Dopuštanje advokatima da upravljaju situacijom rešavanja problema;

- Odavanje utiska "gubljenja” i „odugovlačenja” vremena, radi koristi.

Menadžeri za odnose s javnošću moraju saopštiti javnosti ono što on ili ona znaju što pre je moguće. Jer u slučajevima velikih kriza koje karakterišu bilo kakvi oblici panike i straha, organizacija treba što češće da komunicira sa javnošću. Obnavljanje i osvežavanje informacija mora da se dešava konstantno i prema određenom pravilu sa kojim su unapred upoznati predstavnici medija (svakih pola sata, sat, dva sata...). Naročito treba izbegavati ćutanje o problemu ili odugovlačenje odgovora.

\section{UZROCI KRIZE}

Krizni menadžment simptome i uzroke krize preduzeća, zbog svoje prirodne povezanosti, teško može precizno razgraničiti i odvojeno analizirati. Simptomi krize su, u suštini, samo indicije sa odgovarajućim obeležjima na osnovu kojih je moguće identifikovati postojanje krize preduzeća. Najznačajniji uzroci krize su: nedostatak sopstvenog kapitala, problemi sa prodajom, greške menadžmenta; Uzroci krize mogu biti locirani eksterno (stanje u privredi recesija, zakonski propisi - zabrana uvoza, gubitak tržišta, štrajkovi, političke krize) i interno (slabosti menadžmenta, nedostatak kontrole, itd.). Brojni simptomi krize mogu biti različiti i sa promenljivim spoljnim manifestacijama. Upravo zbog toga in je često otežano prepoznati kao prave uzročnike krize. Moguće je da simptomi krize budu zasnovani na slučajnostima ili sa istim ili sličnim indikacijama kao i pravi uzroci krize preduzeća. Potom, neki simptomi mogu ostati nezapaženi, a neki, opet, ne moraju da potiču od neke od vrsti krize preduzeća. Navedeni, i drugi specijalni razlozi, mogu značajno otežati izvođenje pravilnog zaključka o tome dali je preduzeće uopšte u krizi ili u kojoj vrsti krize. $\mathrm{Na}$ primer, simptomi krize likvidnosti mogu se ispoljiti kroz konstantni nedostatak slobodnih novčanih sredstava, pad Cash Flow-a, potreba povećanja stepena zaduženosti, povećanje troškova finansiranja, zahtevi poverilaca za avansnim plaćanjem, porast obaveza po osnovu gotovinskih ekvivalenata (hartija od vrednosti).Simptomi krize uspeha preduzeća se, sintetizovano uzev, ispoljavaju padom rentabiliteta, odnosno pogoršavanjem zarađivačke sposobnosti preduzeća, a što je, opet globalno uzev, propraćeno obeležjima: smanjenja poslovnih prihoda, neadekvatnim smanjenjem ili zadržavanjem na istom nivou, ili čak i povećavanjem troškova preduzeća, nezadovoljstvo i zabrinutost top i middle menadžmenta, nagoveštaji ili/i odlasci nekih 
menadžera i eksperata iz preduzeća. Kriza preduzeća uglavnom nastaje delovanjem više povezanih činilaca različitog intenziteta. Moguće su i situacije kod kojih kod kojih su identični simptomi, uzroci i posledice krize. Sve ovo ukazuje na složenost identifikovanja $\mathrm{i}$ analize uzroka krize preduzeća.

Eksterni uzroci krize potiču iz privrednosistemskog ambijenta u kome preduzeće funkcioniše. Najvažniji uzroci ovog porekla mogu biti: nepovoljna kretanja na tržištu inputa (nabavke), konjukturne oscilacije, mere konkurencije, promene kurseva stranih sredstava plaćanja, mere poreske i socijalne politike, politike subvencioniranja, mere zaštite životne sredine i drugi eksterni uzroci neekonomske prirode ratovi, socijalni potresi, prirodne nesreće i slično.

Interni uzroci krize su, s aspekta zastupljenosti, mogućnosti uticaja i značaja - bitniji u odnosu na eksterne. U pitanju su uzroci koji nastaju i deluju unutar preduzeća, a mogu biti brojni i sistematizovani na različite načine (Mecintosh, 1996, p. 23). Međutim, interni uzroci krize uglavnom potiču od nekompentnosti menadžmenta, kao rukovodeće strukture po nivoima odlučivanja i po funkcionalnim područjima poslovnih aktivnosti.

Uzroci krize u oblasti upravljačkih aktivnosti menadžmenta mogu biti izazvani neadekvatnim (Thompson, 2002):

- postavljanjem ciljeva,

- izborom odgovarajućih strategija,

- finansijskim i projektnim planiranjem,

- prilagođavanjem tehničko-tehnološkom progresu,

- organizacionom prilagođavanju,

- motivacionom sistemom preduzeća,

- funkcionisanjem sistema kontrole, i

- rešenjima u informisanju i komuniciranju;

Uzroci krize mogu biti locirani po određenim funkcionalnim područjima.

Međutim, iz krize je nemoguće izaći sa istim onim menadžersko-liderskim stilovima (kodovima) koji su krizu izazvali. Niti je iz krize moguće izaći samo sa jednim tipom koda, a naročito ne sa onima koji ispoljavaju osobine koje vode u krizu (Adižes, 2003): patološki „osnivači“, „palikuće“, „supersledbenici“, „drugorazredni treneri“. Centralizacija, preterana kontrola, nedoslednost, radoholičarstvo, konfliktnost, egocentričnost i egoizam, izbegavanje samostalnog donošenja odluka, nebriga o efikasnosti, odsustvo društvenog senzibiliteta, odsustvo ideja, neorganizovanost, nestručnost, neprilagodljivost, odsustvo osećaja za svet oko sebe i nesistematičnost doveli su do krize, pa menadžeri i lideri sa takvim osobinama ne mogu ni izvesti iz nje.

\section{PRIPREMA KOMUNIKACIJE U KRIZI \\ PLANA}

U momentu nastupanja krize od velike je važnosti popis svih neophodnih postupaka, potrebnih ljudi i resursa sa kojima treba ostvariti komunikaciju. Nepostojanje planova u pisanom obliku zahteva ulaganje dodatnog vremena i truda, što u kriznoj situaciji može da predstavlja otežavajući faktor.

Plan mora biti kratak, jezgrovit i prilagodljiv, kako bi se mogao uspešno upotrebljavati $u$ nepredviđenim okolnostima, odnosno u bilo kakvoj krizi. (Novak, 2001, p. 156) Ovaj plan mora da sadrži:

1. Uvodni deo sa opisom zadataka, poslovnom filozofijom, misijom, vizijom, ciljevima i načinom upotrebe ovog plana.

2. Način postupanja u krizi

3. Krizni štab sa popisom imena, njihovim kratkim biografijama, opisom njihove odgovornosti, telefonskim brojevima koji moraju biti dostupni $24 \mathrm{~h}$, kao i pojedinostima o njihovoj zameni.

4. Spisak javnosti: svih ključnih činioca u krizi, način kontaktiranja, adrese, telefonski brojevi, zakonodavna tela, članova Vlade i njenih institucija, advokata..

5. Obaveštenja: popis i obrasci različitih vrsta obaveštenja za uspešnu komunikaciju u krizi.

6. Spisak izvora i lokacija: lokacija krizne sobe (prostorije u kojoj će se održavati sastanci kriznog štaba), lokacija konferencijske sale, raspoloživih izvora i način njihove upotrebe. $U$ krizi su dobrodošli i modernizovani planovi lokacija opasnih materijala, skladišta sigurnosne opreme, planovi gašenja požara, alternativnih izvora vode, spisak oštećenih ili opasnih područja i otpada.

7. Mediji: popis medija sa spiskom imena novinara, telefonskim brojevima, adresama, e-mail kontaktima, kao i kratak priručnik o načinu komunikacije sa medijima. 
8. Informacije o kompaniji: kopije podataka o kompaniji, proizvodima, upotrebljivim tehničkim podacima, kratak istorijat firme...

9. Ostalo: dodatne potrebne i važne informacije

Sam plan nema veliku vrednost ukoliko nije testiran, i određenim treningom simuliran, uzimajući u obzir njegovu razumljivost i upotrebljivost. Kada kompanija krene u pripremu kriznog plana, put za reagovanje na moguću krizu je apsolutno otvoren. Ipak, ističe se šest etapa u kreiranju kriznog plana (Blek, 2003, pp. 167-169):

1. Analiziranje mogućih uzroka neprilika Kada se razmatra predlog za usvajanje kriznog plana, korisna je prethodno pažljiva procena eventualnih poteškoća, koje bi mogle da predstavljaju prepreku u savladavanju krize. Time će se rukovodstvo kompanije uveriti da su predložene mere razumne i neophodne. Posle takve analize, neophodno je podneti pismenu procenu koju formalno mora odobriti rukovodstvo.

2. Pripremanje plana - Kada početne analize i predloge potvrdi i odobri rukovodstvo, sledeću fazu predstavlja razrada detaljnog plana koji bi dao odgovor na sve potencijalne pretnje.

3. Selekcija ljudskih resursa - Od mnogih članova kriznog tima zahteva se da naprave listu kadrova, koja bi bila na raspolaganju u trenutnku kada se nesreća dogodi. To ljudstvo mora biti sposobno da odgovara na telefonske pozive i da kontaktira sa predstavnicima štampe, koji će biti mnogobrojni u slučaju ozbiljne krize sa gubitkom ljudskih života. Iskustvo i praksa pokazuju da su sekretarice najviše dorasle takvoj vrsti posla. Kada se prave liste, moraju se pokriti sva 24 časa.

4. Komunikacijski kapaciteti - Pažljivo se mora razmotriti na koji način će se rešavati problem opterećenosti komunikacijskih linija u kriznim situacijama. Sa susednim kompanijama se može postići dogovor o korišćenju telefonskih ili faks linija. Ako kompanija ima stalno angažovane konsultantske agencije, treba in pozvati $\mathrm{i}$ zadužiti za kontakt sa medijima.

5. Obuka - Odabrani kadrovi moraju da pohađaju obuku kako bi bili potpuno spremni da deluju u trenutku izbijanja krize
6. Simuliranje krizne situacije - $U$ različitim vremenskim intervalima neophodno je organizovati nenajavljene vežbe, u saradnji sa policijom i drugim lokalnim organizacijama. Bitno je da te vežbe budu što realističnije, kako bi mogle pravilno da se procene i kako bi pružile dragocene informacije. Ukoliko se vežba snimi video kamerom, kasnije se može organizovati diskusija sa učesnicima vežbe.

\section{REŠENJA KRIZNIH SITUACIJA}

Rešenje kriznih situacija preduzeća podrazumeva preduzimanje čitavog niza mera u zavisnosti od vrste krize, područja nastanka krize - eksterna i/ili interna, u jednom ili više funkcionalnih područja i drugih činilaca.Strategijskom kriznom menadžmentu, uglavnom, ostaju na raspolaganju tri moguća pravca akcija sintetizovanih kroz sledeće strategije:

- povlačenje (dezinvestiranje),

- konsolidovanje (investiranje),

- restrukturiranje (ofanzivna strategija);

Sa aspekta operativnog kriznog menadžmenta upravljanje krizom preduzeća podrazumeva adekvatne pojedinačne i sintetizovane mere na povećanju tražnje, proizvodnje, prodaje i prihoda od prodaje, $s$ jedne strane i mere sračunate na snižavanje troškova primenom adekvatnih tehnika za upravljanje troškovima preduzeća. Krizni menadžment za popravljanje statusa likvidnosti preduzeća ima zadatak da odgovarajućim merama otkloni uzroke tekuće nelikvidnosti. Međutim, prisutne su određene poteškoće u razgraničavanju mera i upravljačkih aktivnosti za sprečavanje krize i "redovnih" mera sračunatih na realizaciju osnovnih ekonomskih ciljeva i uspeha preduzeća uopšte. Ipak, sprečavanje krize preduzeća dobija posebno mesto putem odgovarajućih strategija i instrumenata koji se primenjuju za ostvarivanje ovako postavljenog specijalnog cilja - cilja sprečavanja krize preduzeća.

Rešenje krize se odnosi na sve mere i aktivnosti kriznog menadžmenta koje imaju za cilj da se preduzeće uspešno sanira i nastavi dalje uspešno poslovanje, ili pak prinudno gašenje kroz postupak stečaja. Nema sumnje da se prednost, zbog interesa stejkholdera, daje sanaciji preduzeća. Sanacija preduzeća, pre svega, podrazumeva 
donošenje određenih poslovno-finansijskih odluka koje se odnose na:

- određivanje ciljeva saniranja,

- izbor i realizaciju odgovarajućih strategija,

- preduzimanje odgovarajućih sanacionih mera na realizaciji sanacionih programa i projekata;

Neosporno, saniranje preduzeća obuhvata široko područje mera i upravljačkih aktivnosti kriznog menadžmenta preduzeća. U zavisnosti od toga koje funkcionalno područje je izvor i koja vrsta krize je u pitanju biće odabrane odgovarajuće strategije, sanacione programe, projekte i sanacione mere.

\section{ZAKLJUČAK}

Krize poslovanja preduzeća su neželjene pojave ali, u savremenim uslovima poslovanja, ponekad i neminovne. One mogu biti izazvane različitim uzrocima - eksternim i/ili internim. U kriznom menadžmentu dominira mišljenje o potrebi razlikovanja strategijskih kriza, kriza uspeha i kriza likvidnosti. Menadžment preduzeća u takvim okolnostima, uopšte ili specijalno, poprima ulogu kriznog menadžmenta. Upravljačke aktivnosti kriznog menadžmenta na otkrivanju simptoma i uzroka krize, kao i na sanaciji krize, bazirane su na osnovnim i specijalnim računovodstvenim izveštajima, kao dispozitivnim i kontrolnim upravljačkim instrumentima.

Saglasno prihvaćenoj i analiziranoj klasifikaciji siptoma i uzroka krize, krizni menadžment se može podeliti na: strategijski, operativni i finansijski krizni menadžment, koji se može dalje diferencirati za krizni menadžment za savladavanje krize likvidnosti i krizni menadžment za savladavanje krize solventnosti.

Strategijski krizni menadžment, s aspekta prevencije, treba da zaštiti postojeće potencijale i pretpostavke za realizaciju osnovnih ekonomskih ciljeva i uspeha preduzeća, odnosno da pravovremeno uoči i ukloni prepreke na putu uspešne budućnosti preduzeća.

Operativni krizni menadžment ima zadatak da otkloni opasnosti krize uspeha preduzeća: opasnostiza ostvarivanje ciljne prodaje, poslovnih prihoda i rentabilnosti poslovanja preduzeća.

Krizni finansijski menadžment se odnosi na pogoršan kratkoročni finansijski položaj preduzeća, odnosno stanje nelikvidnosti preduzeća i na pogoršan dugoročni imovinski položaj preduzeća, odnosno stanje nesolventnosti.

Krizni menadžment, između ostalog, predstavlja posebnu formu upravljanja preduzećem s ciljem eliminisanja uzroka krize, odnosno savladavanje krize preduzeća kroz proces sanacije. Sanacione mere podrazumevaju donošenje više poslovnofinansijskih odluka sračunatih na sprečavanje $i$ savladavanje krize preduzeća, a ne na njegovu likvidaciju.

U rešavanju krizne situacije, bitna uloga pripada funkciji odnosa $s$ javnošću koja treba pravovremeno, transparetno i iskreno prikaže situaciju u javnosti, osigura potpuno i kontinuirano izveštavanje, objavi sve raspoložive informacije, čak i kada situacija ide neželjenim i neprijatnim tokom i da pokaže svoje nastojanje da kontroliše, ukloni ili redukuje potencijalne posledice.

Osnova za upravljanje kriznom situacijom je njeno planiranje, odnosno predviđanje i planiranje onoga što se može dogoditi. Odnosi s javnošću u kriznim situacijama uključuju aktivnosti koje se odnose na to šta je moguće uraditi da se takva situacija spreči.

Sigurno je da će krizni plan omogućiti kompaniji da se uhvati u koštac sa iznenadnom krizom i pružiti šansu da izbegne teškoće u komunikaciji sa medijima, ali su praksa $\mathrm{i}$ iskustvo pokazali da svaka kriza ukazuje na različite probleme i segmente kompanije. Krize raznih vrsta mogu da pogode neku kompaniju ili organizaciju, ali osnovna pravila ponašanja u kriznim situacijama su gotovo ista za sve. Detalji svakako zavise od okolnosti i prirode krize.

Većina kriznih situacija se može predvideti, tako da je moguće izvršiti pripreme iako su trajanje i intenzitet krize neizvesne kategorije. Odnosi s javnošću moraju da obezbede i omoguće konstantan priliv informacija, čak i kada je situacija nepromenjena ili se kreće u željenom pravcu. Svojom transparentnošću i dugoročnim aktivnostima, kompanija demonstrira da su joj sigurnost pojedinca (potrošača) i šire grupacije (društvene zajednice) prioritet.

Dakle, neizvesnost u poslovanju preduzeća nije nikada bila veća nego u sadašnjim uslovima sa izrazitom tenfencijom ka povećanju u budućnosti. $\mathrm{U}$ takvim uslovima menadžer se, umesto 
pravljenja budžeta, uz široku primenu modela simulacije, često zasnovanih na matematičkoj racionalnosti, ali koji su već u momentu sačinjavanja bili oborivi u polaznim pretpostavkama, orijentiše ka tzv."kliznom i reaktivnom" predviđanju. U tom kontekstu, menadžer, komercijalista i radnik moraju znati kako reagovati na sve moguće situacije tokom proizvodnje proizvoda i to u njihovoj potpunoj saglasnosti. Menadžer tada nije samo učesnik u postizanju konvergencije ciljeva već i učesnik u iznalaženju različitih mogućih scenarija za razvoj sposobne reaktivne organizacije.

\section{CITIRANI RADOVI}

Adižes, I. (2003). Upravljanje životnim ciklusima preduzeća, Beograd: Grmeč-Privredni pregled. Novi Sad: Adižes menadžment konsalting.

Antoni, D. (2005). Public relations od A do Z. Novi Sad: Adizes.

Blek, S. (2003). Odnosi s javnošću. Beograd: Clio.

Mecintosh, B. (1996). Management Accounting and Control System. Chichester: John Wiley \& Sons.

Novak, B. (2001). Krizno komuniciranje i upravljanje opasnostima. Zagreb: Binoza Press.

Senić, R. (1996). Krizni menadžment. Beograd: BMG.

Thompson, J. L. (2002). Strategic Management: awareness and change, 4th ed. London: Thomson Press.

Weston, J., Mitchell, M., \& Mulherin, J. (2004). Takeovers, Restructuring, and Corporate Governance, Fourth Edition. New Jersey: Prentice Hall.

Datum prve prijave:

Datum prijema korigovanog članka:

Datum prihvatanja članka:
31.03.2016.

04.06.2016.

23.06.2016.

Kako citirati ovaj rad? / How to cite this article?

Style - APA Sixth Edition:

Petrović, P., \& Živković, A. (2016, July 15). Krizni menadžement kao deo strateškog menadžmenta uslužnih kompanija. (Z. Čekerevac, Ed.) FBIM Transactions, 4(2), 120-128. doi:10.12709/fbim.04.04.02.12

Style - Chicago Sixteenth Edition:

Petrović, Pero, and Aleksandar Živković. 2016. "Krizni menadžement kao deo strateškog menadžmenta uslužnih kompanija." Edited by Zoran Čekerevac. FBIM Transactions (MESTE) 4 (2): 120-128. doi:10.12709/fbim.04.04.02.12.

Style - GOST Name Sort:

Petrović Pero and Živković Aleksandar Krizni menadžement kao deo strateškog menadžmenta uslužnih kompanija [Journal] // FBIM Transactions / ed. Čekerevac Zoran. - Belgrade : MESTE, July 15, 2016. - 2 : Vol. 4. - pp. 120-128.

Style - Harvard Anglia:

Petrović, P. \& Živković, A., 2016. Krizni menadžement kao deo strateškog menadžmenta uslužnih kompanija. FBIM Transactions, 15 July, 4(2), pp. 120-128.

Style - ISO 690 Numerical Reference:

Krizni menadžement kao deo strateškog menadžmenta uslužnih kompanija. Petrović, Pero and Živković, Aleksandar. [ed.] Zoran Čekerevac. 2, Belgrade : MESTE, July 15, 2016, FBIM Transactions, Vol. 4, pp. 120-128. 